\title{
rRNA gene RFLP as an identification tool for Corynebacterium species
}

\author{
Johanna Björkroth, ${ }^{1}+$ Hannu Korkeala ${ }^{1}$ and Guido Funke ${ }^{2}$ \\ Author for correspondence: Johanna Björkroth. Tel: +35897084 9705. Fax : +358970849718. \\ e-mail: johanna.bjorkroth@helsinki.fi
}

\footnotetext{
1 Department of Food and Environmental Hygiene, University of Helsinki, PO Box 57, 00014 Helsinki University, Finland

2 Department of Medical Microbiology, Gärtner \& Colleagues Laboratories, D-88250 Weingarten, Germany
}

\begin{abstract}
The value of rRNA gene RFLP analysis (ribotyping) as a tool for Corynebacterium and Turicella species identification was evaluated. Seventyfour strains representing $\mathbf{2 6}$ different species or subspecies were analysed by BstEll, Smal and Sphl ribotyping. Numerical analysis of the resulting rDNA banding patterns was performed by Dice coefficient correlation in order to establish a database for species identification. In general, most of the strains belonging to the same species clustered together. Interestingly, BstEII clustering of many species followed known phylogenetic lineages. This was not evident with the more heterogeneous Smal and Sphl patterns. The Smal patterns contained a $\mathbf{1 8 0 0}$ bp band in the digests of all species studied with the exception of Corynebacterium urealyticum. Sphl digestion resulted in the most heterogeneous patterns. The information provided by all three enzymes was considered essential for the reliable linking of strains of unknown identity with defined species in the database. It is concluded that ribotyping provides an useful tool for screening and characterization of potentially new Corynebacterium species.
\end{abstract}

Keywords: Corynebacterium, rRNA gene restriction patterns, ribotyping, identification, taxonomy

\section{INTRODUCTION}

Within the group of coryneform bacteria (i.e. aerobic, asporogenous, non-partially acid-fast, irregular, Gram-positive rods), the genus Corynebacterium contains the largest number of defined species (40 in March 1998). Bergey's Manual of Systematic Bacteriology (Collins \& Cummins, 1986) lists only 16 valid Corynebacterium species; however, between 1987 and 1995, 12 new species were defined (Funke et al., 1997d), and between 1996 and March 1998, another 11 new species were defined. Most of the species described during 1986-1998 were isolated from human clinical samples. The identification of corynebacteria from clinical samples, together with the appearance of newly established species, is still causing confusion for laboratories not used to dealing with the characteristics of this diverse genus.

Since it is most likely that a plethora of further new Corynebacterium species will be described in the near

\footnotetext{
†Present address: Federal Research Centre for Nutrition, Institute for Hygiene and Toxicology, Haid- und Neustraße 9, D-76131 Karlsruhe, Germany.
}

future, it was considered appropriate to evaluate the application of rRNA gene restriction fragment patterns (ribotyping) as a means of identification of coryneforms. The concept of ribotyping was established in the 1980s (Grimont \& Grimont, 1986) and it has been used mainly for tracing the possible clonality of epidemiologically associated isolates. However, it was originally described as a potential tool for taxonomy and it is now used more and more for species identification. Several studies have shown that ribotyping deals with a genetically constant feature, resulting in species-specific bands or typical banding patterns within a species. For Gram-positive microbes, it has been used for identification within the genera Enterococcus (Hall et al., 1992), Streptococcus (Rudney \& Larson, 1993), Lactobacillus (Björkroth \& Korkeala, 1996, 1997) and Leuconostoc-Weissella (Björkroth et al., 1998).

The systematic use of ribotyping within the genus Corynebacterium has never been studied before. This study set out to evaluate the potential of this technique for the identification of Corynebacterium species. Several restriction enzymes were evaluated in order to establish a revealing database aiding the identification of these bacterial species. 


\section{METHODS}

Strains. Seventy-one strains representing 25 different medically relevant Corynebacterium species or subspecies were used in the present study (Table 1). All strains originated from epidemiologically unrelated patients and belonged to the culture collection of the Department of Medical Microbiology, University of Zürich (DMMZ), established by G. Funke. Turicella otitidis was included because this genus is the closest phylogenetic neighbour of the genus Corynebacterium (Pascual et al., 1995; Ruimy et al., 1995) and the taxon is often confused with Corynebacterium species in the routine clinical laboratory (Funke et al., 1997d).

Isolation of DNA. Depending on the growth rate, strains were incubated for $18-48 \mathrm{~h}$ at $37^{\circ} \mathrm{C}$ on Columbia agar base (Gibco-BRL) supplemented with sheep blood (7\%). For the lipophilic species, this medium was also supplemented with $1 \%$ Tween 80 (Merck). After checking colony morphology, a cell mass of $30 \mathrm{mg}$ wet weight was scraped from the plate and used for DNA isolation. DNA was isolated by the guanidium thiocyanate method (Pitcher et al., 1989) with the modification of a combined lysozyme and mutanolysin treatment (Björkroth \& Korkeala, 1996).

Selection of restriction enzymes for ribotyping. Initially, 15 restriction enzymes, BamHI, BglII, Bss HII, BstEII, ClaI, DpnII, DraI, EcoRI, HindIII, SacII, SgrAI, SmaI, SpeI, SphI and SspI (New England Biolabs), were tested for ribotyping of Corynebacterium-Turicella by using two strains, Corynebacterium auris $328^{\mathrm{T}}$ and T. otitidis 272 .

Ribotyping. Restriction endonuclease treatment of $2 \mu \mathrm{g}$ DNA was done as specified by the manufacturer (New

Table 1. Strains used in the study

Strains were obtained from the Culture Collection of the Department of Medical Microbiology, University of Zürich (DMMZ) or the Swiss Culture Collection for Bacteria (LA).

\begin{tabular}{|c|c|c|c|}
\hline Taxon & Strain & Taxon & Strain \\
\hline \multirow[t]{3}{*}{ C. accolens } & DMMZ $1882^{\mathrm{T}}$ & C. jeikeium & DMMZ $1111^{\mathrm{T}}$ \\
\hline & DMMZ 1883 & & DMMZ 1949 \\
\hline & DMMZ 1351 & C. macginleyi & DMMZ $1352^{\mathrm{T}}$ \\
\hline \multirow[t]{4}{*}{ C. afermentans subsp. afermentans } & DMMZ $545^{\mathrm{T}}$ & & DMMZ 228 \\
\hline & DMMZ 1305 & C. minutissimum & LA $3512^{\mathrm{T}}$ \\
\hline & DMMZ 1829 & & DMMZ 693 \\
\hline & DMMZ 1768 & & DMMZ 790 \\
\hline \multirow[t]{3}{*}{ C. afermentans subsp. lipophilum } & DMMZ $872^{\mathrm{T}}$ & C. mucifaciens & DMMZ $2278^{\mathrm{T}}$ \\
\hline & DMMZ 1620 & & DMMZ 216 \\
\hline & DMMZ 1764 & & DMMZ 300 \\
\hline \multirow[t]{3}{*}{ C. amycolatum } & DMMZ $455^{T}$ & C. propinquum & DMMZ 1319 \\
\hline & DMMZ 2427 & & DMMZ 1814 \\
\hline & DMMZ 2460 & & DMMZ 2068 \\
\hline \multirow[t]{3}{*}{ C. argentoratense } & DMMZ $1336^{\mathrm{T}}$ & C. pseudodiphtheriticum & LA 3518 \\
\hline & DMMZ 1187 & & DMMZ 2120 \\
\hline & DMMZ 1619 & & DMMZ 2283 \\
\hline \multirow[t]{3}{*}{ C. auris } & DMMZ $328^{\mathrm{T}}$ & C. pseudotuberculosis & DMMZ 960 \\
\hline & DMMZ 355 & & DMMZ Ctb4 \\
\hline & DMMZ 399 & & DMMZ 962 \\
\hline \multirow[t]{3}{*}{ C. confusum } & DMMZ $2439^{\mathrm{T}}$ & C. riegelii & DMMZ $2415^{\mathrm{T}}$ \\
\hline & DMMZ 3259 & & DMMZ 2582 \\
\hline & DMMZ 3364 & & DMMZ 3128 \\
\hline \multirow[t]{3}{*}{ C. coyleae } & DMMZ $214^{\mathrm{r}}$ & C. striatum & LA $3520^{\mathrm{T}}$ \\
\hline & DMMZ 1075 & & DMMZ 1527 \\
\hline & DMMZ 1415 & & DMMZ 1728 \\
\hline \multirow[t]{3}{*}{ C. diphtheriae } & DMMZ $2401^{\mathrm{T}}$ & C. ulcerans & DMMZ 957 \\
\hline & DMMZ 1188 & & DMMZ 958 \\
\hline & DMMZ 1314 & & DMMZ 959 \\
\hline \multirow[t]{2}{*}{ C. durum } & DMMZ $2705^{\mathrm{T}}$ & C. urealyticum & DMMZ 34 \\
\hline & DMMZ 2740 & & DMMZ 874 \\
\hline \multirow[t]{3}{*}{ C. falsenii } & DMMZ $2537^{\mathbf{T}}$ & & DMMZ 1028 \\
\hline & DMMZ 2569 & C. xerosis & DMMZ $1504^{T}$ \\
\hline & DMMZ 2570 & & DMMZ 2543 \\
\hline \multirow[t]{3}{*}{ C. glucuronolyticum } & DMMZ $838^{\mathrm{T}}$ & & DMMZ 3296 \\
\hline & DMMZ 842 & T. otitidis & DMMZ $234^{\mathrm{T}}$ \\
\hline & DMMZ 944 & & DMMZ 262 \\
\hline C. imitans & DMMZ $2023^{\mathrm{T}}$ & & DMMZ 272 \\
\hline
\end{tabular}


England Biolabs). Southern transfer and hybridization were performed as outlined previously (Björkroth \& Korkeala, 1996). The rDNA probe for ribotyping was labelled by reverse transcription (AMV-RT; Promega) by using Dig DNA label (Boehringer Mannheim) as described before (Blumberg et al., 1991). A lambda HindIII digest (Boehringer) was applied three times in each gel to allow normalization between the different electrophoresis runs.

Ribotyping data management. Membranes were scanned by a Hewlett Packard ScanJet 4c/T scanner. Numerical analysis of banding patterns was performed using the GELCOMPAR software version 4.0 (Applied Maths). The similarity between all pairs was expressed by Dice coefficient correlation and UPGMA (unweighted pair group method using arithmetic averages) clustering was used for construction of the dendrogram.

\section{RESULTS AND DISCUSSION}

Of the 15 restriction enzymes tested, BstEII, HindIII, $S m a I$ and $S p h$ I digestion resulted in good cleavage of DNA from the test strains with revealing ribotypes. These four enzymes were selected for use for the remaining 72 strains. Since the use of HindIII resulted in incomplete digestion with many of the strains, numerical analysis of the strains was performed for $B s t$ EII, SmaI and SphI ribotypes.

$B s t$ EII ribotypes generally had fewer bands (two to 11) (Fig. 1) than the ribotypes obtained with the two other restriction enzymes (Figs 2 and 3). In particular, BstEII cleavage resulted in patterns with few high-molecularmass fragments. For most species, all strains tested clustered together (e.g. Corynebacterium falsenii, Corynebacterium xerosis, Corynebacterium amycolatum, Corynebacterium riegelii, C. auris, T. otitidis, etc.), whereas, for example, the three strains of Corynebacterium confusum (Funke et al., 1998) and the three strains of Corynebacterium propinquum did not (Fig. 1). When only a few high-molecular-mass fragments with only slight differences in location on a membrane are formed, the numerical analysis is prone to error. This can be seen in the interpretation of Corynebacterium afermentans subsp. afermentans 1620 and T. otitidis 272 patterns (Fig. 1). These patterns were recognized as identical; however, when inspected visually, the two low-molecular-mass fragments do not share the same location. This problem could be circumvented by extended gel running times. It is interesting to note that many phylogenetically closely related species, like Corynebacterium jeikeium and $C$. falsenii (Sjödén et al., 1998), $C$. xerosis and $C$. amycolatum (Pascual et al., 1995; Ruimy et al., 1995), Corynebacterium mucifaciens and $C$. afermentans (Funke et al., 1997b), Corynebacterium coyleae and $C$. afermentans (Funke et al., 1997c), Corynebacterium accolens and Corynebacterium macginleyi (Ruimy et al., 1995) and Corynebacterium ulcerans and Corynebacterium pseudotuberculosis (Pascual et al., 1995; Ruimy et al., 1995) clustered together. This observation was made exclusively in BstEII patterns and it may be due to the presence of fewer cleavage sites in the area where the rRNA genes are located, resulting in homogeneous patterns within phylogenetic neighbours.

SmaI ribotyping patterns of Corynebacterium species showed between five and 12 bands (Fig. 2). Interestingly, all species tested except the three C. urealyticum strains showed a common band of approximately $1800 \mathrm{bp}$. This fragment may be cleaved from within the rRNA gene itself, in an area constant for the coryneform species. Again, most of the strains belonging to the same species clustered together and only a few species, like Corynebacterium minutissimum, presented heterogeneous patterns.

SphI ribotyping patterns of corynebacteria showed between two and nine bands (Fig. 3). In general, heterogeneity of these ribotyping patterns was greater than for the other two restriction enzymes. Strains belonging to the species $C$.xerosis, $C$. urealyticum, $C$. minutissimum, $C$. afermentans subsp. lipophilum and Corynebacterium durum did not cluster together. However, all strains belonging to each of these species, with the exception of $C$. minutissimum, did cluster together when at least one of the three enzymes was used for ribotyping. Therefore, it is concluded that a combination of the three enzymes is essential in order to identify these medically relevant Corynebacterium species. Since each enzyme provides a different characterization result, no general threshold similarity value can be set within a species. Most of the species exhibited similarity values of 50 to $100 \%$ between strains when clustered together (Figs 1-3).

So far, ribotyping of Corynebacterium species has been used mainly for strain tracking or large-scale epidemiological investigations. The majority of studies (applying restriction enzyme BstEII) have focussed on Corynebacterium diphtheriae (De Zoysa et al., 1995; Popovic et al., 1996; Riegel et al., 1997) as the most significant pathogen within the genus Corynebacterium. Further studies used ribotyping (restriction enzymes HindIII, PvuII and BstEII) to demonstrate nosocomial transmission of $C$. jeikeium (Pitcher et al., 1990) as well as transmission of Corynebacterium imitans between non-hospitalized persons (Funke et al., 1997a). However, ribotyping (with restriction enzymes $P v u$ II and EcoRI) has also been applied successfully in taxonomic descriptions of $C$. afermentans (Riegel et al., 1993b) and C. propinquum (Riegel et al., 1993a). These authors demonstrated clearly that both $C$. afermentans and $C$. propinquum could be identified by ribotyping when multiple restriction enzymes were applied. In a comprehensive study, Soto et al. (1991) observed, based on numerical analysis of rRNA gene patterns (restriction enzymes $H$ HindII and EcoRI), that the former CDC coryneform group D-2 bacteria (synonymous with $C$. urealyticum) clustered together and represented a taxon separate from the other established corynebacteria. For the non-medical corynebacteria, Liebl et al. (1991) demonstrated that ribotyping (applying restriction 

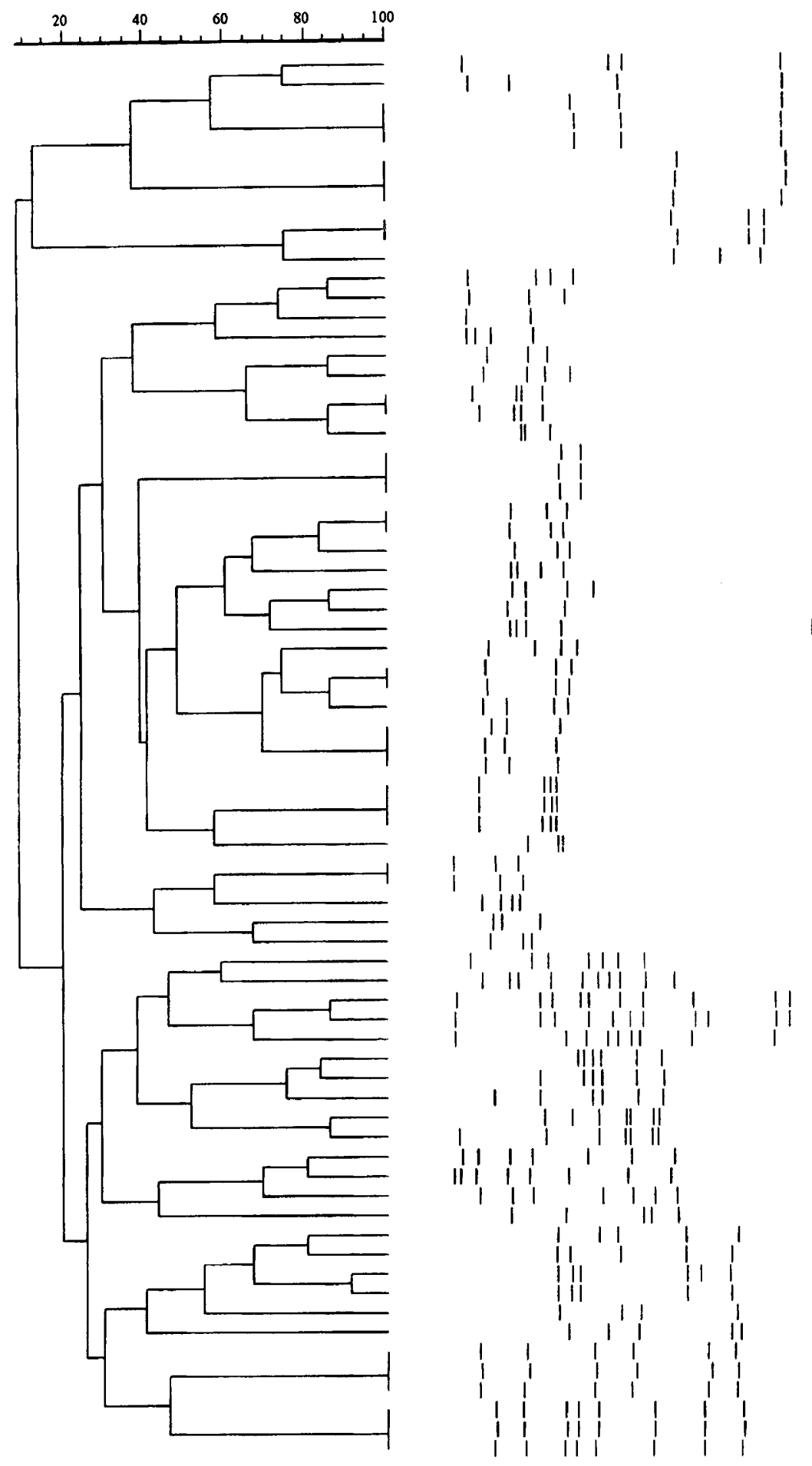

\begin{tabular}{|c|c|}
\hline $\begin{array}{l}\text { Corynebacterium jeikeium } \\
\text { Corymebacterium jeikeium }\end{array}$ & $\begin{array}{l}1111^{\mathrm{T}} \\
1949\end{array}$ \\
\hline Corynebacierium falsenii & $2537^{T}$ \\
\hline Corymebacterium falsenii & 2569 \\
\hline Corymebacteriwm falsenil & 2570 \\
\hline Corymebacterium xerosis & $1504^{\mathrm{T}}$ \\
\hline Corynebacterium xerosis & 2543 \\
\hline Corymebacterium xerosis & 3296 \\
\hline Corynebacterium amycolatum & $455^{T}$ \\
\hline Corymebacterium amycolatum & 2460 \\
\hline Corynebacteritum amycolatum & 2427 \\
\hline Corynebacterium riegelii & $2415^{\mathrm{T}}$ \\
\hline Corynebacteriam riegelii & 3128 \\
\hline Corymebactertum riegelii & 2582 \\
\hline Conmebactertum mimusissimum & 790 \\
\hline Corynebacterium propingurm & 2068 \\
\hline Corymebacterium confusum & 3364 \\
\hline Corymebacterium striatum & 1527 \\
\hline Corynebacterium striatum & 1728 \\
\hline Corynebacterium propinquum & 1319 \\
\hline Corynebacterium auris & $328^{\mathrm{T}}$ \\
\hline Corymebacterium auris & 355 \\
\hline Corynebacterium auris & 399 \\
\hline Corynebacterium afermentans ssp. lipophilum & 1620 \\
\hline Turicella otitidis & 272 \\
\hline Turicella otitidis & 262 \\
\hline Turicella otitidis & $234^{T}$ \\
\hline $\begin{array}{l}\text { Cormebactertum afermentans ssp. lipophilum } \\
\text { Corymebactertum confusum }\end{array}$ & $\begin{array}{l}1764 \\
3259\end{array}$ \\
\hline Corynebacterium afermentans ssp. afermentans & 1829 \\
\hline Corymebactertum mucifaciens & 300 \\
\hline Corynebacterium mucifaciens & $2278^{T}$ \\
\hline Corynebacterium mucifaciens & 216 \\
\hline Corymebacterium afermentans ssp. afermentans & $545^{T}$ \\
\hline Corynebacterium afermentans ssp. afermentans & 1305 \\
\hline Corymebacterium afermentans ssp. afermentans & 1768 \\
\hline Corynebacterium afermentans ssp. lipophitum & $872^{\mathrm{T}}$ \\
\hline Corymebacterium coyleae & $214^{\mathrm{T}}$ \\
\hline Corynebacterium coyleae & 1075 \\
\hline Corynebacterium coyleae & 1415 \\
\hline Corynebacterium confusum & $2439^{\mathrm{T}}$ \\
\hline Corymebacterium pseudodiphtheriticum & LA3518 \\
\hline Corynebacterium pseudodiphtheriticum & 2283 \\
\hline $\begin{array}{l}\text { Corynebacterium minutissimum } \\
\text { Corynebacterium mimutisstmum }\end{array}$ & $\begin{array}{l}693 \\
\text { LA351 }\end{array}$ \\
\hline Corymebacterium propinquum & 1814 \\
\hline Corynebacterium durum & $2705^{T}$ \\
\hline Corynebacterium durum & 2740 \\
\hline Corymebacterium diphtheriae & $2401^{T}$ \\
\hline Corynebacterium diphtheriae & 1188 \\
\hline Corynebacterium diphtheriae & 1314 \\
\hline Cormebacterium accolens & $1882^{\mathrm{T}}$ \\
\hline Corymebacterium accolens & 1883 \\
\hline Corymebacterium accolens & 1351 \\
\hline Corynebacterium macginleyi & $1352^{\mathrm{T}}$ \\
\hline Corymebacterium macginleyi & 228 \\
\hline Corynebacterium argentoratense & $1336^{\mathrm{T}}$ \\
\hline Corynebacterium argentoratense & 1619 \\
\hline Corynebacterium argentoratense & 1187 \\
\hline Corymebacterium imitans & $2023^{\mathrm{T}}$ \\
\hline Corymebacterium urealyticum & 34 \\
\hline Corynebacterium ghucuronolyticum & 842 \\
\hline Corynebacterium ghucuronolyticum & $838^{\mathrm{T}}$ \\
\hline Corymebacterium ghucuronolyticum & 944 \\
\hline Corynebacterium urealyticum & 1028 \\
\hline Corynebacterimm urealyticum & 874 \\
\hline Corymebacterium ulcerans & 957 \\
\hline Corynebacterium ulcerans & 958 \\
\hline Corymebacterium ulcerans & 959 \\
\hline Corynebacterium pseudotuberculosis & 960 \\
\hline Corynebacterium pseudotuberculosis & Ctb4 \\
\hline Corynebacterium pseudotuberculosis & 962 \\
\hline
\end{tabular}

Fig. 1. BstEll dendrogram and ribotypes; left, high molecular mass ( $23 \mathrm{kbp})$ and right, low molecular mass ( $500 \mathrm{bp})$.

enzymes BamHI, HindIII or BglI) leads to the correct identification of Corynebacterium glutamicum strains.

It remains unclear to us why, despite of the promising results of Liebl et al. (1991) and Soto et al. (1991), the application of ribotyping for Corynebacterium iden- tification has not been investigated in more detail before. It is possible that the availability of sophisticated scanning hardware and statistical cluster analysis software, together with a commercial automated system for ribotyping (Qualicon), will lead to increased interest in this method. Obviously, the 

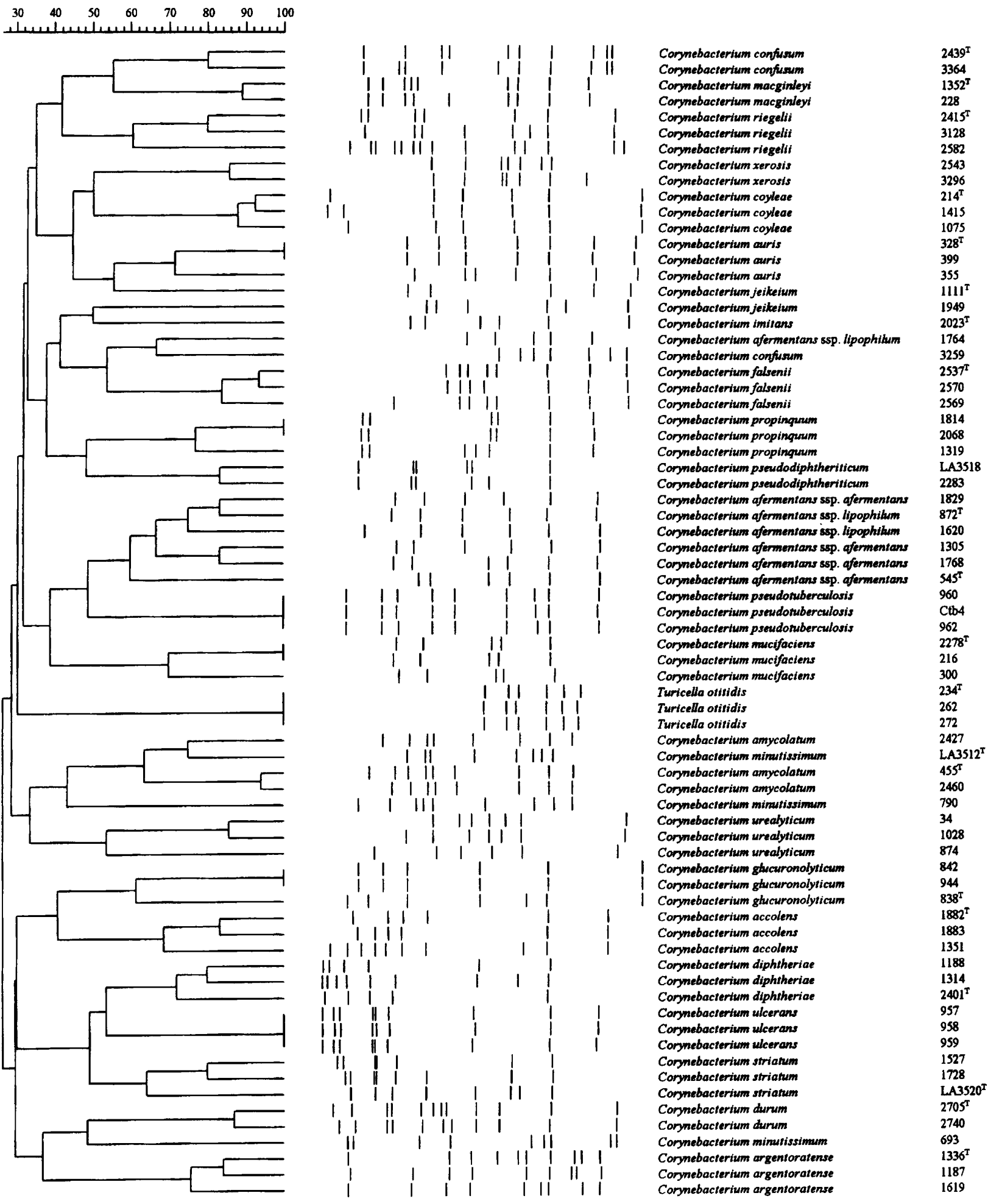

Fig. 2. Smal dendrogram and ribotypes; left, high molecular mass ( $23 \mathrm{kbp}$ ) and right, low molecular mass (500 bp).

application of ribotyping to identification of Corynebacterium species is only possible after the creation of a comprehensive database, as in the present study. Once this has been done, it is not particularly timeconsuming or labour-intensive to screen individual unidentified Corynebacterium strains for their identity. We acknowledge that it may have been desirable to test many more strains of each of the 26 species or subspecies included, but the primary goal of our study was to demonstrate the general applicability of our 


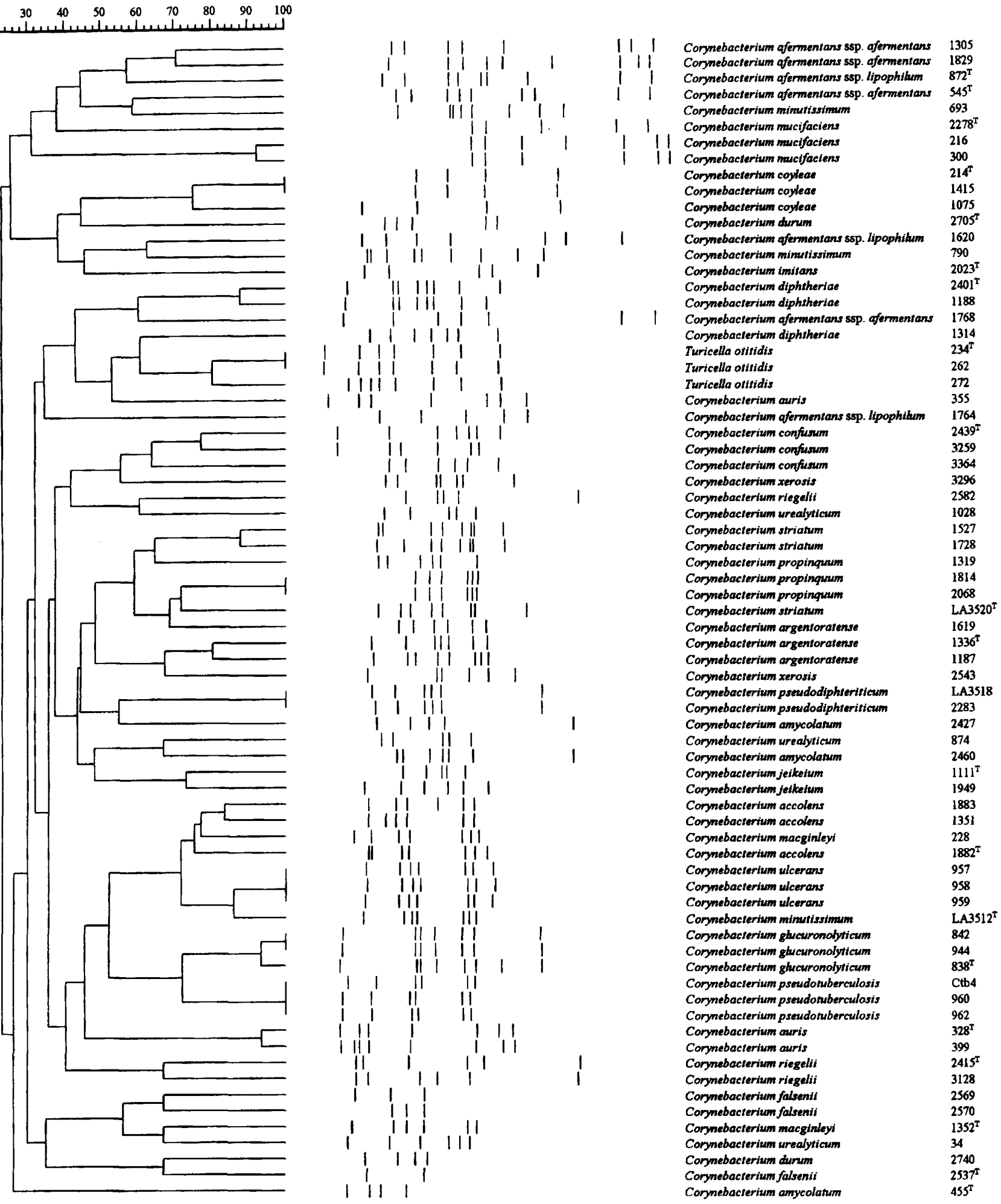

Fig. 3. Sphl dendrogram and ribotypes; left, high molecular mass ( $23 \mathrm{kbp})$ and right, low molecular mass (500 bp).

approach for the medically relevant members of the genus Corynebacterium. In our view, ribotyping is a complementary method for screening unidentified corynebacteria.
Other established methods used for identifying new Corynebacterium species include analysis of the 16S-23S rRNA intragenic spacer region (Aubel et al., 1997 ) and the use of whole-cell protein profiles (Sjödén 
et al., 1998). Species delineation within the genus Corynebacterium has often been achieved by sequencing of full 16S rRNA genes (Pascual et al., 1995; Ruimy et al., 1995), because the genus exhibits an enormous phylogenetic depth. Compared to other genera, 16S rDNA divergence rates are relatively high within the genus Corynebacterium (Pascual et al., 1995; Ruimy et al., 1995), which allows new Corynebacterium species to be established on the basis of 16S rRNA gene sequences. However, if sequencing facilities are not available, we consider ribotyping as a useful initial approach to test whether an unidentified Corynebacterium strain represents a new species.

\section{ACKNOWLEDGEMENTS}

We thank Mrs Sirkka Ekström for her excellent technical assistance. G.F. is the recipient of an ESCMID research fellowship and the work of J. B. is supported financially by the Academy of Finland.

\section{REFERENCES}

Aubel, D., Renaud, F. N. R. \& Freney, J. (1997). Genomic diversity of several Corynebacterium species identified by amplification of the 16S-23S rRNA gene spacer regions. Int $J$ Syst Bacteriol 47, 767-772.

Blumberg, H. M., Kiehlbauch, J. A. \& Wachsmuth, I. K. (1991). Molecular epidemiology of Yersinia enterocolitica $0: 3$ infections: use of chromosomal DNA restriction fragment length polymorphisms of rRNA genes. J Clin Microbiol 29, 2368-2374.

Björkroth, J. \& Korkeala, H. (1996). rRNA gene restriction patterns as a characterization tool for Lactobacillus sake strains producing ropy slime. Int J Food Microbiol 30, 293-302.

Björkroth, J. \& Korkeala, H. (1997). Lactobacillus fructivorans spoilage of tomato ketchup. J Food Protein 60, 505-509.

Björkroth, J., Vandamme, P. \& Korkeala, H. (1998). Identification and characterization of Leuconostoc carnosum, associated with production and spoilage of vacuum-packaged, sliced, cooked ham. Appl Environ Microbiol 64, 3313-3319.

Collins, M. D. \& Cummins, C. S. (1986). Genus Corynebacterium. In Bergey's Manual of Systematic Bacteriology, vol. 2, pp. 1266-1276. Edited by P. H. A. Sneath, N. S. Mair, M. E. Sharpe \& J. G. Holt. Baltimore: Williams \& Wilkins.

De Zoysa, A., Efstratiou, A., George, R. C., Jahkola, M., VuopioVarkila, J., Deshevoi, S., Tseneva, G. \& Rikushin, Y. (1995). Molecular epidemiology of Corynebacterium diphtheriae from northwestern Russia and surrounding countries studied by using ribotyping and pulsed-field gel electrophoresis. $J$ Clin Microbiol 33, 1080-1083.

Funke, G., Efstratiou, A., Kuklinska, D., Hutson, R. A., De Zoysa, A., Engler, K. H. \& Collins, M. D. (1997a). Corynebacterium imitans sp. nov. isolated from patients with suspected diphtheria. J Clin Microbiol 35, 1978-1983.

Funke, G., Lawson, P. A. \& Collins, M. D. (1997b). Corynebacterium mucifaciens sp. nov., an unusual species from human clinical material. Int $J$ Syst Bacteriol 47, 952-957.

Funke, G., Pascual Ramos, C. \& Collins, M. D. (1997c). Corynebacterium coyleae sp. nov., isolated from human clinical specimens. Int J Syst Bacteriol 47, 92-96.

Funke, G., von Graevenitz, A., Clarridge, J. E., III \& Bernard, K. A. (1997d). Clinical microbiology of coryneform bacteria. Clin Microbiol Rev 10, 125-159.

Funke, G., Osorio, C. R., Frei, R., Riegel, P. \& Collins, M. D. (1998). Corynebacterium confusum sp. nov., isolated from human clinical specimens. Int J Syst Bacteriol 48, 1291-1296.

Grimont, F. \& Grimont, P. A. D. (1986). Ribosomal ribonucleic acid gene restriction patterns as potential taxonomic tools. Ann Inst Pasteur Microbiol 137B, 165-175.

Hall, L. M. G., Duke, B., Guiney, M. \& Williams, R. (1992). Typing of Enterococcus species by DNA restriction fragment analysis. J Clin Microbiol 30, 915-919.

Liebl, W., Ehrmann, M., Ludwig, W. \& Schleifer, K. H. (1991). Transfer of Brevibacterium divaricatum DSM 20297' ' Brevibacterium flavum' DSM 20411, 'Brevibacterium lactofermentum' DSM 20412 and DSM 1412, and Corynebacterium lilium DSM $20137^{\mathrm{T}}$ to Corynebacterium glutamicum and their distinction by rRNA gene restriction patterns. Int $J$ Syst Bacteriol 41, 255-260.

Pascual, C., Lawson, P. A., Farrow, J. A. E., Navarro Gimenez, M. \& Collins, M. D. (1995). Phylogenetic analysis of the genus Corynebacterium based on 16S rRNA gene sequences. Int J Syst Bacteriol 45, 724-728.

Pitcher, D. G., Saunders, N. A. \& Owen, R. J. (1989). Rapid extraction of bacterial genomic DNA with guanidium thiocyanate. Lett Appl Microbiol 8, 151-156.

Pitcher, D., Johnson, A., Allerberger, F., Woodford, N. \& George, R. (1990). An investigation of nosocomial infection with Corynebacterium jeikeium in surgical patients using a ribosomal RNA gene probe. Eur J Clin Microbiol Infect Dis 9, 643-648.

Popovic, T., Kombarova, S. Y., Reeves, M. W., Nakao, H., Mazurova, I. K., Wharton, M., Wachsmuth, I. K. \& Wenger, J. D. (1996). Molecular epidemiology of diphtheria in Russia, 1985-1994. J Infect Dis 174, $1064-1072$.

Riegel, P., de Briel, D., Prévost, G., Jehl, F. \& Monteil, H. (1993a). Proposal of Corynebacterium propinquum sp. nov. for Corynebacterium group ANF-3 strains. FEMS Microbiol Lett 113, 229-234.

Riegel, P., de Briel, D., Prévost, G., Jehl, F., Monteil, H. \& Minck, R. (1993b). Taxonomic study of Corynebacterium group ANF-1 strains: proposal of Corynebacterium afermentans sp. nov. containing the subspecies $C$. afermentans subsp. afermentans subsp. nov. and $C$. afermentans subsp. lipophilum subsp. nov. Int J Syst Bacteriol 43, 287-292.

Riegel, P., Freitas, F. I. S., Prévost, G. \& 9 other authors (1997). Comparison of traditional and molecular methods for typing nontoxigenic strains of Corynebacterium diphtheriae. Eur J Clin Microbiol Infect Dis 16, 610-614.

Rudney, J. D. \& Larson, C. J. (1993). Species identification of oral viridans streptococci by restriction fragment polymorphism analysis of rRNA genes. J Clin Microbiol 31, 2467-2473.

Ruimy, R., Riegel, P., Boiron, P., Monteil, H. \& Christen, R. (1995). Phylogeny of the genus Corynebacterium deduced from analyses of small-subunit ribosomal DNA sequences. Int J Syst Bacteriol 45, 740-746.

Sjödén, B., Funke, G., Izquierdo, A., Akervall, E. \& Collins, M. D. (1998). Description of some coryneform bacteria isolated from human clinical specimens as Corynebacterium falsenii sp. nov. Int J Syst Bacteriol 48, 69-74.

Soto, A., Pitcher, D. G. \& Soriano, F. (1991). A numerical analysis of ribosomal RNA gene patterns for typing clinical isolates of Corynebacterium group D2. Epidemiol Infect 107, 263-272. 